\title{
Spatial variability of hydraulic conductivity of saturated soil in a conservation unit
}

\section{Glaucia Machado Mesquita ${ }^{1}$, Felipe Corrêa Veloso dos Santos $^{2}$, Anne Louise Dores ${ }^{2}$, Vladia Correchel $^{1}$}

${ }^{1}$ Universidade Federal de Goiás, Goiânia, Goiás, Brasil. E-mail: agroglaucia@gmail.com, vladiaea@ufg.br

${ }^{2}$ Pontifícia Universidade Católica de Goiás, Goiânia, Goiás, Brasil. E-mail: felipesantos@pucgoias.edu.br; annelouisedemelo@gmail.com

Received: 19/07/2021; Accepted: 19/12/21.

\begin{abstract}
The study aimed to evaluate the hydraulic conductivity using soil samples with undisturbed structure in the soil layers of 0-5, 5-10, 10-20, and 20-40 cm; 120 soil samples were collected. For the determination of hydraulic conductivity, the constant load permeameter was used. For geostatistical analysis, exploratory data analysis was performed using frequency histograms, determining the main measures of position and dispersion, verifying the trends for the construction of boxplot graphics, which allows the identification of discrepant points. The lowest and highest hydraulic conductivity values were found in the $20-40 \mathrm{~cm}$ and $0-5 \mathrm{~cm}$ soil layers, respectively; values commonly found in soils under forest conditions. Based on the results, we conclude when the soil sampling for analysis of hydraulic conductivity is random, the minimum distance between the points must be greater than 15.5 $\mathrm{m}$.
\end{abstract}

Keywords: Soil physical quality indicator, Permanent preservation areas, Soil water, Permeability.

\section{Variabilidade espacial da condutividade hidráulica do solo saturado em uma unidade de conservação}

\section{RESUMO}

O objetivo deste trabalho foi avaliar a condutividade hidráulica, foram utilizadas amostras com estrutura indeformada, nas profundidades de 0-5, 5-10, 10-20 e 20-40 cm, sendo coletado 120 amostras. Para a determinação da condutividade hidráulica foi utilizado o permeâmetro de carga constante. Para análise geoestatística foi realizada a análise exploratória dos dados por meio de histogramas de frequência, determinadas as principais medidas de posição e dispersão, verificadas as tendências para construção dos gráficos boxplot, os quais permitem a identificação de pontos discrepantes. Na profundidade $20-40 \mathrm{~cm}$, foi encontrado o menor valor de condutividade hidráulica $\left(1.52 \mathrm{~mm} \mathrm{~h}^{-1}\right)$ e o maior $\left(407.44 \mathrm{~mm} \mathrm{~h}^{-1}\right)$ na profundidade $0-5 \mathrm{~cm}$, valores esses, em geral, encontrados em solos sob mata. Pode-se concluir pelos resultados obtidos que quando a amostragem do solo para análise da condutividade hidráulica for aleatória, a distância mínima entre os pontos deve ser superior a $15.5 \mathrm{~m}$.

Palavras-chave: Indicador de qualidade física do solo, Área de preservação permanente, Água no solo, Permeabilidade.. 


\section{Introduction}

The hydraulic conductivity of the soil is a property that expresses the ease with which the water moves in it, being extremely important to agricultural use and, consequently, to the production of crops and the preservation of the soil and the environment (Gonçalves and Libardi, 2013). Hydraulic conductivity corresponds to the permeability of the soil to allow water to flow between its empty spaces.

When saturated, clay soils have lower hydraulic conductivity than sandy and gravel soils. Depending on the percolation intensity of the subsoil water, the permeability of soil can be classified. The classification of permeability is made based on Darcy's Law, so a soil with hydraulic conductivity greater than $0.36 \mathrm{~mm} \mathrm{~h}^{-1}$ is classified as permeable, and those with permeability lower than that value, impermeable (Karmann, 2000).

Guerra (2018) reports that vegetation is a crucial factor for soil maintenance and, consequently, directly influences water infiltration. In this matter, conservation units or reference forests have significant importance as an indicator of soil physical quality. The loss of this quality directly affects the porous space of the soil, impairing the supply of water and oxygen, limiting the development of plants and the activity of organisms in the soil (Tormena et al., 1998).

In this sense, the study aimed to determine the maximum distance between the points to evaluate the spatial variability of the hydraulic conductivity of saturated soil in a conservation unit, using the method of constant load permeameter in the laboratory.

\section{Material and Methods}

The Amalia Hermano Teixeira Botanic Garden (AHTBG) is the largest Conservation Unit of Goiânia, with a total area of $1,000,000 \mathrm{~m}^{2}$, located between the geographic coordinates, $16^{\circ} 43^{\prime} 12^{\prime \prime}$ and $16^{\circ} 43^{\prime} 50^{\prime \prime} \mathrm{S}$ and $49^{\circ} 15^{\prime} 40^{\prime \prime}$ and $49^{\circ} 14^{\prime} 40^{\prime \prime} \mathrm{W}$, in the southern region of Goiânia-GO. It presents vegetation cover characterized by primary forest, Semidecidual Seasonal Forest type, constituting the phytophysiognomy of greater exuberance in the domains of the Cerrado biome. The region has a humid tropical climate of aw-type according to the Köeppen classification. The soil was classified as Latossolo Vermelho distrófico (LVd) according to the Brazilian Soil Classification SystemSiBCS (Santos et al., 2018).

Thirty undisturbed soil samples were collected in volumetric rings $(5 \times 5 \mathrm{~cm})$ per layer $(0-5,5-10,10-20$, and $20-40 \mathrm{~cm}$ ), totaling 120 samples. The midpoint was adopted to represent the depth of interest in the 10-20 and 20-40 cm soil layers. The sampling mesh consisted of six rows and five columns with a $10 \mathrm{~m}$ between the sampling points, forming a gride of $300 \mathrm{~m}^{2}$. After collecting the rings, these were wrapped in PVC-type film plastic and placed in a Styrofoam box. This way, soil structure is preserved, and there is a reduction of the effect of the impacts caused during transport.

In the Soil Physics Laboratory of the School of Agronomy of the Federal University of Goiás (Universidade Federal de Goiás), the soil samples were prepared using a sharp blade to remove excess soil from the ends of the ring, leaving only the soil that fills the ring. After this process, the samples were placed to saturate with distilled water in four trays. At first, a 1 $\mathrm{cm}$ water depth was set, maintained for 6 hours. After this period, another $1 \mathrm{~cm}$ depth of water was added, kept for 18 hours. After the first 24 hours, a further $2 \mathrm{~cm}$ of water depth was added. The $4 \mathrm{~cm}$ water depth was maintained for 48 hours or until $75 \%$ or more of the samples from each tray presented a saturation signal, adopting the visual criterion of sample mirroring. The ambient temperature was maintained at $23^{\circ} \mathrm{C}( \pm 0.5)$ during this process.

The hydraulic conductivity of the saturated soil was determined with the use of a constant load permeameter with a load of $4 \mathrm{~cm}$. It contained a $500 \mathrm{~mL}$ graduated cylinder. The collected volume was recorded every 25 $\mathrm{mL}$, and the time spent was recorded with a digital stopwatch with an accuracy of 0.1 seconds and stored in a microcomputer. Water temperature was monitored with a mercury thermometer with an accuracy of $0.1^{\circ} \mathrm{C}$.

In each sample, at least twenty times the hydraulic conductivity was determined. To estimate the mean conductivity in each sample, data were taken from the first three and last three readings. In addition, the values used were consecutive readings (more than three) that presented an amplitude equal to or less than $10 \%$ of the mean sequence of each sample. The conductivity value adjustment of each sample to the temperature of $20^{\circ} \mathrm{C}$ was performed, as described in Embrapa (1997).

The statistical analysis of the data was made from the descriptive analysis, determining the amplitude, maximum, minimum, mean (arithmetic, geometric, and harmonic), median, deviations (standard, interquartile, and geometric), quartile (first and third), standard error, asymmetry, kurtosis, and frequency histogram. The criteria and sequence of the procedures of the analyses used are present in detail in Spiegel (2009) and Lapponi (2005). After the descriptive analysis, the spatial continuity analyses were performed according to the generated semivariograms. The semivariogram model was validated using the Jackknife method according to Vieira et al. (2010). After adjusting and validating the semivariograms, the data were estimated by ordinary kriging, and the values found were used to predict the nonsampled values. 


\section{Results and Discussion}

Table 1 presents the descriptive analysis of hydraulic conductivity of a saturated Latossolo in a Conservation Unit. At the soil layer between 0 and $40 \mathrm{~cm}$, the mean hydraulic conductivity value was $67.89 \mathrm{~mm} \mathrm{~h}^{-1}$ with an amplitude of $405.91 \mathrm{~mm} \mathrm{~h}^{-1}$. On average, conductivity values decreased as soil depth increased $\left(116.8 \mathrm{~mm} \mathrm{~h}^{-1}\right.$; $82.55 \mathrm{~mm} \mathrm{~h}^{-1} ; 43.62 \mathrm{~mm} \mathrm{~h}^{-1}$ and $\left.30.23 \mathrm{~mm} \mathrm{~h}^{-1}\right)$, and the heterogeneity of the data followed the same pattern except for the 20-40 cm depth, as shown in Table 1

In general, among the data obtained, the lowest hydraulic conductivity value found was $1.52 \mathrm{~mm} \mathrm{~h}^{-1}$. The highest value was $407.44 \mathrm{~mm} \mathrm{~h}^{-1}$ in the $20-40 \mathrm{~cm}$ soil layer, the lowest conductivity value was obtained, while the largest was found in the $0-5 \mathrm{~cm}$ depth. These values express how much this attribute can vary in such a small area $\left(300 \mathrm{~m}^{2}\right)$; the difference between the highest and lowest value is 268 times. This variation results from interactions of soil attributes related to structural arrangement.

The amplitude per soil layer followed the expected pattern (Reichardt and Timm, 2012) except for the 20$40 \mathrm{~cm}$ soil layer, as can be seen with the values of $393.45 \mathrm{~mm} \mathrm{~h}^{-1}(0-5 \mathrm{~cm}), 273.51 \mathrm{~mm} \mathrm{~h}^{-1}(5-10 \mathrm{~cm})$, $216.83 \mathrm{~mm} \mathrm{~h}^{-1}(20-40 \mathrm{~cm})$, and $108.54 \mathrm{~mm} \mathrm{~h}^{-1}(10-20$ $\mathrm{cm})$. In general, this decreases with the observed depth. It is observed that the conductivity values of the firstclass intervals represent the mean (Figure 1), and except for the $20-40 \mathrm{~cm}$ depth, the conductivity area presents the same pattern of independent variation.

Positive asymmetry was observed in the histogram of the $20-40 \mathrm{~cm}$ soil layer, while in the $10-20 \mathrm{~cm}$ layer, it was multimodal in decreasing scales. In the $5-10 \mathrm{~cm}$ and $0-5 \mathrm{~cm}$ layers, the shape is not clearly defined, with the former approaching a bimodal curve and the $0-5 \mathrm{~cm}$ layer with a positive asymmetric with the presence of a plateau. These characteristics in the shape of the curves of the histograms observed are consistent with the amplitudes, deviations, means, and coefficient of variation found in Table 1 (Spiegel, 2009). These characteristics are observed in detail in Figure 2.

The extreme values observed in Figure 2 distanced from the symmetrical shape. In addition, in Table 1, Figures 1 and 2 , the distribution of hydraulic conductivity is in a transition environment bagween normal, exponential, and gamma distribution. In general, when the hydraulic conductivity is analyzed assuming that there is no spatial dependence, it transforms to fit the normal distribution, adapting to the assumptions of the analysis of variance (Kutilek, 2004, Scherpinski et al., 2010).

The observed values presented normal distribution only in the $10-20 \mathrm{~cm}$ soil layer, while the $0-5$ and $5-10$ $\mathrm{cm}$ soil layers adjusted to the normal distribution after the transformation of $\operatorname{Ln}(x)$ and the $20-40 \mathrm{~cm}$ layer when transformed by $\operatorname{Ln}(x+1)$.

Table 1. Descriptive analysis of hydraulic conductivity of a saturated Latossolo in a Conservation Unit.

\begin{tabular}{lllll}
\hline & $--10-20 \mathrm{~cm}$ & $20-40 \mathrm{~cm}$ \\
\hline Parameter & $0-5 \mathrm{~cm}$ & $5-10 \mathrm{~cm}$ & 108.54 & 216.83 \\
\hline Total Amplitude & 393.45 & 273.51 & 39.31 & 24.25 \\
Median & 93.97 & 6791 & 21.93 & 14.54 \\
First Quartile & 67.91 & 45.24 & 58.07 & 32.60 \\
Third Quartile & 135.81 & 95.23 & 36.14 & 18.06 \\
Interquartile Deviation & 67.91 & 49.99 & 43.62 & 30.23 \\
Arithmetic Mean & 116.80 & 82.55 & 28.40 & 38.03 \\
Standard Deviation & 84.77 & 55.11 & 5.19 & 6.94 \\
Standard Error & 15.74 & 10.06 & 65.11 & 125.80 \\
Coefficient of Variation (\%) & 72.57 & 66.76 & 0.84 & 4.42 \\
Asymmetry & 1.68 & 2.07 & 0.01 & 22.12 \\
Kurtosis & 3.83 & 6.11 & 26.57 & 11.83 \\
Harmonic Mean & 65.39 & 57.82 & 34.71 & 20.14 \\
Geometric Mean & 90.69 & 68.99 & 1.26 & 1.47 \\
Variance (geometric) & 1.30 & 1.17 & 2.07 & 2.57 \\
Standard Deviation (geometric) & 2.16 & 1.84 & & \\
\hline
\end{tabular}




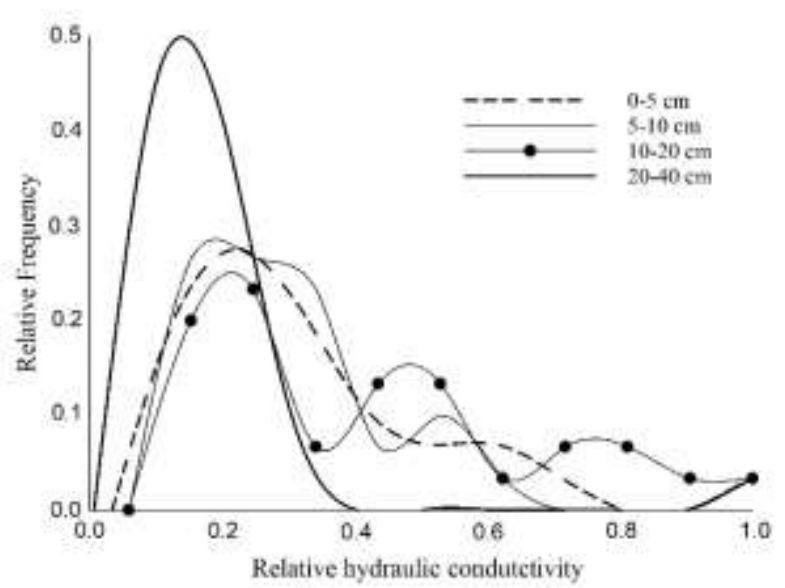

Figure 1. Histogram of frequency of hydraulic conductivity of a Latossolo in a conservation unit.

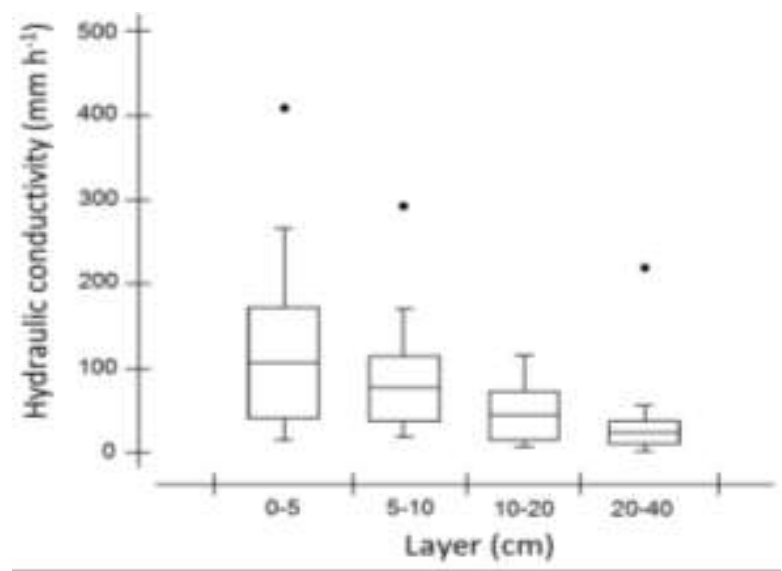

Figure 2. Hydraulic conductivity boxplot graph for $0-40 \mathrm{~cm}$ soil layers.

The reaches (a) ranged from 15.42 to $12.66 \mathrm{~m}$, indicating the spatial correlation amplitude between the observations of each variable. The determination coefficient $\left(\mathrm{R}^{2}\right)$ indicates how much of the total variation is common to the elements that constitute the analyzed pairs. The closer to one, the more the phenomenon resulting from combining the two layers studied is explained (Table 2).

According to Ferraz et al. (2012), the nugget effect was and still is an important parameter in the semivariogram, indicating an unexplained variability considering the sampling distance used. Expressed as a percentage of the plateau, this parameter aims to facilitate the comparison of the degree of spatial dependence of the variables under study (Ecco et al., 2012). The random component observed is small in the relative nugget effect, less than 0.15 . Conductivity estimates show a ratio of $\mathrm{C} 0 /(\mathrm{C} 0+\mathrm{C} 1)$ higher than 0.8 , which makes it difficult to differentiate statistical and geostatistical randomness (Yamamoto and Landim, 2013; Rodrigues et al., 2019).

The reach showed low variability, and there were no very elongated tails in the distribution of attributes, which could compromise the kriging estimates based on average values (Figure 2). The preserved environment, Conservation Unit, presents a high water infiltration rate in the soil profile (Table 1). Silva (2012) observed that the process of water infiltration into the soil, being this closer to natural conditions, the higher the infiltration rate found.

Corroborating the study by Lima et al. (2014) obtained, working with a sample of forest area, in layer 20-40 $\mathrm{cm}$ they obtained saturated hydraulic conductivity in the laboratory of $140.4 \mathrm{~mm} \mathrm{~h}^{-1}$, which represents fast conductivity, in an area of cultivation of the Caupi culture, they obtained $25.8 \mathrm{~mm} \mathrm{~h}^{-1}$ which features a slow to moderate permeability

The range is expected to be greater at the $20-40 \mathrm{~cm}$ soil layer; however, values similar in the $0-5 \mathrm{~cm}$ layer were obtained. This fact may be related to the study area since even being a Conservation Unit, suffers anthropogenic actions as it is located within an urban area.

Table 2. Semivariogram parameters of the Gaussian model $(\mathrm{C} 0, \mathrm{C} 0+\mathrm{C} 1$, and a), degree of variability $(\mathrm{C} 0 /(\mathrm{C} 0+\mathrm{C} 1)$, $\mathrm{R} 2$ of physical attributes of a Latossolo in a conservation unit.

\begin{tabular}{lllll}
\hline & & & \\
\hline Parameter & $0-5 \mathrm{~cm}$ & $5-10 \mathrm{~cm}$ & $10-20 \mathrm{~cm}$ & $20-40 \mathrm{~cm}$ \\
\hline $\mathrm{C} 0$ & 0.023 & 0.001 & 0.001 & 0.001 \\
$\mathrm{C} 0+\mathrm{C} 1$ & 0.574 & 0.387 & 0.569 & 0.900 \\
$\mathrm{a}$ & 12.661 & 13.840 & 15.420 & 12.310 \\
$\mathrm{R}^{2}$ & 0.941 & 0.977 & 0.830 & 0.845 \\
$\mathrm{C} 0 /(\mathrm{C} 0+\mathrm{C} 1)$ & 0.960 & 0.997 & 0.998 & 0.999 \\
Adjusted data & no & no & $\operatorname{Ln}(\mathrm{x})$ & no \\
\hline
\end{tabular}

$\mathrm{C} 0=$ Nugget effect $; \mathrm{C} 0+\mathrm{C} 1=$ Plateau; $\mathrm{a}=$ reach $\mathrm{R}^{2}=$ coefficient of determination. 


\section{Conclusions}

In studies in which spatial dependence in soil sampling for hydraulic conductivity analysis is not considered, the minimum distance between the points should be greater than $15.5 \mathrm{~m}$. The maximum distance between the sampling points in analyses of the spatial variability of hydraulic conductivity should be less than $12 \mathrm{~m}$

\section{Authors' Contribution}

Glaucia Machado Mesquita contributed to the execution of the experiment, data collection, analysis and interpretation of results, writing of the manuscript and final correction of the manuscript. Felipe Corrêa Veloso dos Santos contributes to the collection, laboratory and statistical analysis and graphics creation. Anne Louise Dores contributed to the writing and data analysis. Vladia Correchel contributed to the design of the experimental arrangement and enabled the collection, laboratory analysis and review of references.

\section{Bibliographic References}

Ecco, M., Carvalho, L.A., Ferrari, L.P. 2012. Variabilidade espacial da resistência do solo a penetração em área cultivada com cana-de-açúcar na safra 2008/2009. Agrarian, 5(17), 263 269. DOI: https://doi.org/10.3411/bjdv5n11-287.

EMBRAPA. EMPRESA BRASILEIRA DE PESQUISA AGROPECUÁRIA. 1997. Centro Nacional de Pesquisas de Solos. Manual de métodos de análise de solo. Centro Nacional de Pesquisa de Solos, Rio de Janeiro. 2. ed., 212 p. https://www.agencia.cnptia.embrapa.br/Repositorio/Manual+d e+Metodos_000fzvhotqk02wx5ok0q43a0ram31wtr.pdf. (acessado 07 de janeiro de 2021)

Ferraz, G.A.E.S., Silva, F.M., Carvalho, L.C.C., Alves, M.C.; Franco, B.C. 2012. Variabilidade espacial e temporal do fósforo, potássio e da produtividade de uma lavoura cafeeira. Engenharia Agrícola, Jaboticabal, 32(10), 140-150. DOI: https://doi.org/10.1590/S0100-69162012000100015.

Gonçalves, A.D.M.A., Libardi, P.L. 2013. Análise da determinação da condutividade hidráulica do solo pelo método do perfil instantâneo. Revista Brasileira de Ciência do Solo, 37(5), 1174-1184. DOI: https://doi.org/10.1590/S010006832013000500007. (acessado 13 de fevereiro de 2021)

Guerra, A.J.T. 2018. Processos erosivos nas encostas. In: Guerra, A.J.T., Cunha, S.B. (Orgs). Geomorfologia: uma atualização de bases e conceitos. $14^{\mathrm{a}}$ ed. Bertrand Brasil, Rio de Janeiro.

Karmann, I. 2000. Ciclo da água, água subterrânea e sua ação geológica. In.: Teixeira, W., Toledo, M.C.M., Fairchild, T.R.,
Taioli, F. (Org.). Decifrando a Terra. Oficina de textos, São Paulo. p. 113-138. https://repositorio.usp.br/item/001131146. (acessado 21 de janeiro de 2021)

Kutilek, M. 2004. Soil hydraulic properties as related to soil structure. Soil \& Tillage Research, 79, 175-184. DOI: https://doi.org/10.1016/j/still.2004.07.006.

Lapponi, J.C. 2005. Estatística usando Excel. Elsevier, Rio de Janeiro. p. 473. https://docero.com.br/doc/nx5csxc. (acessado 07 de janeiro de 2021)

Lima, J.R.S., Souza, E.S., Antonino, A.C.D., Silva, I.F., Corrêa, M.M., Lira., C.A.B.O. 2014. Atributos físico-hídricos de um Latossolo Amarelo cultivado e sob mata nativa no Brejo Paraibano. Agrária - Revista Brasileira de Ciências Agrárias. 9(4), .599-605. DOI:10.5039/agraria.v9i4a3532.

Reichardt, K., Timm, L.C. 2012. Solo, Planta e Atmosfera: Conceitos, processos e aplicações. $2^{\mathrm{a}}$ ed. Manole, Barueri.

Rodrigues, M. S., Alves, D. C., Cunha, J. C., Melo Júnior, J. C. F., Lima, A. M. N, Lira, A. L.F, Bernard, F., Silva, K. A. (2019). Soil mapping quality for site-specific management in fruit fields in the semiarid region of Brazil. Ciencia del suelo, $37(2), \quad 328-337 . \quad$ http://www.suelos.org.ar/sitio/volumen-37numero-2-diciembre-2019-2/. (acessado 08 de janeiro de 2021).

Scherpinski, C., Uribe-Opazo, M.A., Vilas Boas, M.A., Sampaio, C.S., Johann, J.A. 2010. Variabilidade espacial da condutividade hidráulica e da infiltração da água no solo. Acta Scientiarum Agronomy, 32, 7-13. DOI: https://doi.org/10.4025/actasciagron.v32i1.959.

Santos, H.G., Jacomine, P.K.T., Anjos, L.H.C., Oliveira, V.A., Lumbreras, J.F., Coelho, M.R., Almeida, J.A., Araújo Filho, J.C., Oliveira, J.B., Cunha, T.J.F. 2018. Sistema brasileiro de classificação de solos. $5^{\text {a }}$ ed. Brasília, Embrapa. https://www.infoteca.cnptia.embrapa.br/handle/doc/1094003. (acessado 07 de janeiro de 2021)

Silva, I.C. 2012. Estudo da capacidade de infiltração de água diante de diferentes usos do solo no município de Itapororoca/PB. Revista Geonorte, Edição Especial, 1(4), 648662. https://www.periodicos.ufam.edu.br/index.php/revistageonorte/article/view/1863. (acessado 13 de fevereiro de 2021).

Spiegel, M.R. (2009). Estatística. $3^{\mathrm{a}}$ ed. Pearson Makron Books, São Paulo.

Tormena, C.A.; Silva, A.P., Libardi, P.L. 1998. Caracterização do intervalo hídrico ótimo de um latossolo roxo sob plantio direto. Revista Brasileira de Ciência do Solo, Viçosa, 22, (4), 573-581. https://doi.org/10.1590/S0100-06831998000400002.

Vieira, S.R.; Carvalho, J.R.T., González, A.P. 2010. Jack Knifing for semivariogram validation. Bragantia, 69, 97-105. https://www.scielo.br/j/brag/a/jkVh6r97gWdHYbDt3QbCp3R /?format=pdf\&lang=en. (acessado 08 de janeiro de 2021)

Yamamoto, J.K., Landim P.M.B. 2013. Geoestatística: conceitos e aplicações. Oficina de Textos, São Paulo. 